This is a postprint (final submitted manuscript) version of the following article:

Parris, D., Bouchet, A., Welty Peachey, J., \& Arnold, D. (2016). Change is hard: Overcoming barriers to adopting a service technology. Journal of Services Marketing, 30(6), 615-629. https://doi.org/10.1108/

JSM-05-2015-0182 


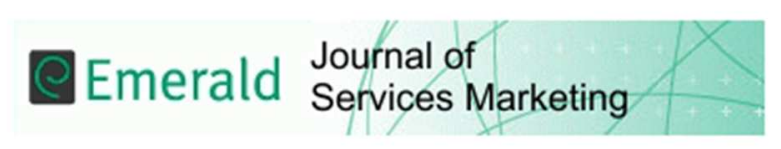

\section{Change is hard: Overcoming barriers to service innovation}

\begin{tabular}{|r|l|}
\hline Journal: & Journal of Services Marketing \\
\hline Manuscript ID & JSM-05-2015-0182.R2 \\
\hline Manuscript Type: & Article \\
\hline Keywords: & $\begin{array}{l}\text { organizational change, customer relationship management, institutional } \\
\text { theory, stakeholder theory, relationship marketing, service innovation }\end{array}$ \\
\hline \multicolumn{2}{|l}{} \\
\hline
\end{tabular}

SCHOLARONE $^{m}$

Manuscripts 


\section{Change is hard: Overcoming barriers to service innovation}

Purpose: Creating value through service innovation requires new processes and ways of communicating to multiple stakeholders. Institutions and stakeholders within the service ecosystem, however, often resist change. Adopting a new service strategy entails two distinct costs - monetary and psychological. The tensions between an organization's need to generate incremental revenue, and the challenges of balancing business as usual and the costs associated with service innovation are explored. Specifically, this article explores the adoption of a customer relationship management (CRM) technology solution in a bureaucratic setting, and the sequence of events needed for successful implementation, with emphasis on overcoming various barriers and hurdles.

Design/methodology/approach: A case study methodology is used to gather and analyze data on how the Arizona State University (ASU) athletic department responded to the changing competitive environment via adopting a CRM technology solution. Data collection consisted of ten semi-structured interviews.

Findings: The experience of ASU illustrates that the primary benefits of a CRM technology solution include the generation of incremental revenue, capturing data, and personalized marketing. The main challenges are coordinating adoption, obtaining commitment, developing competency, estimating costs, and creating content.

Research Implications: A conceptual framework emerged from the data that describes the likelihood of a service technology's successful implementation based upon the interaction of the strength of key actors, organizational situation perception, and organizational commitment. The model extends the proposed duality of service innovation outcomes as either success or failure to acknowledge the likelihood of a partial implementation where marginal success is achieved.

Practical implications: The sequence of events needed for successful implementation of a service technology are highlighted, with emphasis on overcoming various barriers and hurdles. Implementation steps are provided, as well as a model to help pinpoint issues.

Originality/Value: The case study provides insight for overcoming pitfalls and barriers to adopting a new service technology in a traditionally bureaucratic organization where resistance to change is the norm, and innovation is not.

Keywords: organizational change, customer relationship management, institutional theory, stakeholder theory, relationship marketing, service innovation 


\section{Introduction}

Enhancing revenue typically compels marketing managers to build loyal relationships with both potential and existing customers through service innovations. Creating value through service innovation requires new processes and ways of communicating to multiple stakeholders at individual (micro), organizational (meso), and societal (macro) levels (Chandler and Vargo, 2011). Innovation in services often requires changes in various dimensions such as the service concept, client interface, the delivery system, the technology, organizational relations, service products, service processes, and external innovations (Kinstoröm et al., 2013; Dominquez-Péry et al., 2013; Su, 2011). Previous research supports Schumpeter's (1934) view that the process of creative destruction through innovation can lead to economic growth by focusing on the positive effects of service innovation (Christofi et al., 2015; Danjum and Rasli, 2012; Mizik and Jacobson, 2003; Möller et al., 2008; Salunke, 2013; Witell et al., 2015).

Despite the "pro-change" bias in research (Roger, 1962; Witell et al., 2015), perhaps a word of caution is warranted. Although organizations have shown a willingness to adopt service innovations, such as customer relationship management (CRM) technology solutions, reaping the promised economic benefits (Cheng and Krumwiede, 2012; Zhou et al., 2005) of successful implementation - the process of executing the service innovation - has been somewhat elusive (Dickie, 1999; King and Burgess, 2008; Payne and Frow, 2006). A faulty implementation by the organization can actually damage customer relationships (Freedman and Sudoyo, 1999; Hackett, 1990; Rigby et al., 2002). Nine out of ten new service offerings fail (Gourville, 2006) perhaps because implementation has different impacts at different levels (Witell et al., 2015). Technology plays a large role in these innovations (Dabholkar, 2000; Drennan and McCollKennedy, 2003; Timmor and Raymon, 2007; Wünderlich et al., 2015); however, successful 
implementation requires a bundle of capabilities and competencies - human, technological, and organizational (Gadrey et al., 1995) to all synergistically work together. This article suggests the interconnectedness of the organization and its members combined with the perceived external and internal risk associated with adopting a new service innovation (i.e., changing) or staying with the status quo influences success, failure, or partial implementation. Researchers have not sufficiently addressed role of risk in service innovation (Witell et al., 2015).

Service innovations should be implemented with a customer relationship orientation; placing the focus on the customer while developing the relationship into an asset for both stakeholders - the customer and the organization (Jayachandran et al., 2005; Srinivasan and Moorman, 2005). However, achieving a true customer relationship orientation in a bureaucratic setting (organizations with limited autonomy) (Merton, 1957; Mills, 1951) is challenging. One of the main internal risks of service innovation involves managing changes to "business as usual," along with the associated costs.

Implementing a service innovation incurs two distinct costs - monetary and psychological. The monetary costs consist of the cost of the technology, training, and salary, along with implementation costs. The psychological costs are changing the organizational culture and processes, and increased visibility into individual employee contributions through metrics. Organizational change is often hampered by a "business as usual" attitudeisomorphism and dominate logics (Cousens and Slack, 2005; DiMaggio and Powell, 1983) and the strategic task of aligning distinct, overlapping, and intersecting effects at the individual, organizational, and societal levels (Chandler and Vargo, 2011; Witell et al., 2015).

Carlborg et al's. (2014) review and synthesis of service innovation research highlights the need for additional studies to gain a deeper understanding of the interactions of stakeholders 
in the organization's service ecosystem. The majority of studies have examined the paradoxes of adopting a service technology through the lens of customer reactions - satisfaction, readiness, and behavioral intentions (Bolton and Lemon, 1999; Fournier and Mick, 1999; Meuter et al., 2000; Mick and Fournier, 1998; Parasuraman, 2000; Timmor and Rymon, 2007; Zeithaml et al., 1996). However, there is a paucity of research regarding the adoption of service innovations at the organizational level in differing workplace environments (Bull 2003; Nair et al., 2007; Ko et al., 2008; Alshawi et al., 2011). Adopting a service innovation requires navigating and altering the socially complex service ecosystem. Broad organizational buy-in is essential for a service innovation to be a success; however, resistance to change is the norm (Welty Peachey and Bruening, 2011; Hutchinson and Bouchet, 2014). Thus, Guastafsson et al., 2015 call for researchers to think outside of the box and pinpoint issues that are relevant for services marketing and management by exploring core management aspects of integrating technology in a service ecosystem.

The aim of this study, therefore, was to investigate the adoption of a service innovation in a bureaucratic setting, and the sequence of events needed for successful implementation, with emphasis on overcoming various barriers and hurdles. Specifically, the investigation focused on the experience of Arizona State University (ASU) and its athletic department, which was the first major athletic department in the United States to adopt a CRM technology solution. The research questions for this endeavor were as follows: (a) what role do key stakeholders have in gaining formal and informal buy-in? And, (b) what organizational factors impact implementation success? Core management aspects of integrating a service innovation were explored through a multi-disciplinary lens utilizing organizational change theory (institutional theory and stakeholder theory) and informed by sports management and service innovation literature. In 
synthesizing the findings and discussion, practical steps for practitioners for implementing a service technology are provided, along with a proposed conceptual model to predict and test the likelihood of a successful implementation - the model is based upon the interaction of the strength of key actors, organizational situation perception, and organizational commitment. The model extends the proposed duality of service innovation outcomes as either success or failure (Witell et al., 2015) to acknowledge the likelihood of a partial implementation where marginal success is achieved. In addition, the model pinpoints potential issues relevant to service marketers and management and provides propositions for researchers to further test.

\section{Service innovation}

As a result of the disruptive innovation of the Internet, more and more consumers-especially Generation Y (born between 1979 and 1994) and younger generations-expect personalized communication from organizations and brands (Parris, 2013). Personalization facilitates modification of one or more aspects of the marketing mix to target a group of individual customers instead of the entire consumer base (Arora et al., 2008; Peppers and Rogers, 1993; Shaffer and Zhang, 2002) to provide personalized products and services (Arora et al., 2008; Kim, 2002). In order to meet these growing expectations, organizations adopt service innovations - a rebundling of diverse means that create novel resources to benefit actors in a given context (Lusch and Nambisan, 2015), often requiring new organizational designs (Araujo and Spring, 2006).

There is a pro-change bias (Roger, 1962; Witell et al., 2015) that service innovation offers an effective means to develop or refine services and improve service quality (Berry et al., 2006; Chen et al., 2012). Even though the growing expectations of consumers and the advancement of technology has sparked a widely accepted need for organizations to adopt 
service innovation, there is a limited amount of research on: the core management issues in integrating a new technology (Gustafson et al., 2015); the role of risk associated with innovation and its multi-level effects (Witell et al., 2015); how service innovation enhances business performance and customer satisfaction (O'Cass et al., 2013); and on how stakeholders manage the socially complex service ecosystem (Carlborg et al., 2014). Furthermore, theory based frameworks in service innovation are lacking (Chae, 2012) perhaps because innovation research tends to focus on manufacturing (Castro et al., 2011; Kindström et al., 2013).

Service innovation has been explored through three schools of thought: assimilationintroduction of new technology with services and manufacturing having similar issues; demarcation — innovation in the service sector is distinct from manufacturing; and, synthesis — all innovations are service innovations (Castro et al., 2011; Coombs and Miles, 2000). This investigation took the demarcation approach, a logic supported by scholars (Castro et al., 2011; Christofi et al., 2015; Ettlie and Rosenthal, 2011; Nijssen et al., 2006).

Service organizations are notoriously complicated with complex social dynamics and ecosystems. Thus, it is imperative for scholars to explore the individual (micro), organizational (meso), and societal (macro) level impacts of service innovation (Chandler and Vargo, 2011; Vargo and Lusch, 2014). Witell et al., (2015) and Synder et al., (2016) propose dualities are key to understanding service innovation. While exploring the dualities such as adopt-reject, changestatic, or good-bad may provide deeper insight, it limits research to extreme cases; whereas, in actuality, the majority of service innovation implementations fall along a spectrum of success.

Today, most transformative service experiences are powered by technology (Dabholkar, 2000; Drennan and McColl-Kennedy, 2003; Timmor and Raymon, 2007; Wünderlich et al., 2015). Successful implementation of a service technology requires a bundle of capabilities and 
competencies - human, technological, and organizational (Gadrey et al., 1995). Creating value through service innovation "introduces something new into the way of life, organization, timing, and placement of what can generally be described as the individual and collective processes that relate to customers" (Barcet, 2010, p.51). Thus, stakeholders across multiple levels of the organization are impacted, making buy-in critical to success.

\section{Theoretical framework}

An organizational change theory perspective was adopted to guide this investigation. Specifically, institutional theory and stakeholder theory serve as the foundation for helping to understand the role of stakeholders in the adoption of a service technology and to explain the organizational factors impacting implementation. Given that the analysis takes place at the institutional and individual levels, these theories helped to inform the investigation, as numerous previous studies in organizational change have framed their institutional- and individual-level investigations with these two theories, respectively (Cousens and Slack, 2005; Welty Peachey and Bruening, 2011).

\subsection{Institutional theory and organizational change}

Institutional theory enhances our understanding an organization's role in the adoption and implementation of a new service innovation. Institutional theory posits that organizations in a field change their structure to conform to expectations about appropriate design and function (DiMaggio and Powell, 1983). The term "field" describes any organizations within a collective industry. Furthermore, organizational change is often hampered by isomorphism, which has been described as "the constraining process that forces one unit in a population to resemble other units that face the same set of environmental conditions" (DiMaggio and Powell, 1983, p. 149). Research has noted that pressures from regulatory agencies regarding the expectations about the 
best ways to conduct business can affect organizations (DiMaggio and Powell, 1983; Slack and Parent, 2006). The regulatory agencies to which ASU athletics reports, for example, include both the National Collegiate Athletic Association (NCAA) and the Pac 12 Conference - both set expectations on how to do business.

Service marketing is seldom a priority for such bureaucratic institutions. Typically, bureaucratic institutions rely on centralized operations, whereas service marketing requires a customer-centric attitude, which often means pushing decision-making down to lower levels of an organization. Bureaucratic organizations might be uncomfortable with the more decentralized decision-making approach required of service marketing and CRM. The resistance to change in a bureaucratic ecosystem is high because change requires a large shift from centralized operations, departments working in silos, and top-down decision-making to a more decentralized decision-making approach with processes integrated across multiple departments.

Institutional studies illustrate the erosion of dominant logics serve to increase field-level change in organizations (Cousens and Slack, 2005). Dominant logics has been defined as "a central logic - a set of material practices and symbolic construction - which constitutes its organizing principles and which is available to organizations and individuals to elaborate" (DiMaggio and Powell, 1983, p. 248). As an example, the dominant logics regarding the mechanisms for generating revenue within athletic departments have historically consisted of ticket and sponsorship sales, donations, and radio/television rights. However, with the increased costs of operating a Division I athletic program and environmental pressures on university budgets, these dominant logics are eroding, thus opening up the search for new service innovations to increase sales. Market demands and threats posed by competitors are primary 
stimuli for firms to explore innovation as means to change, differentiate themselves, and get ahead of their competition (Lee et al., 2009).

\subsection{Stakeholder theory and organizational change}

Stakeholder theory (Freeman, 1984) provides a framework for exploring how managerial decision-making and planning activities for CRM adoption should address "whether, why, and how" to implement the innovation (Markus and Tanis, 2000, p. 189). Stakeholder theory describes the social contract between business and societies (Quazi, 2003) in which management's purpose is to find the most advantageous balance among the key stakeholder groups: customers, employees, business partners, communities, investors, and the environment (Clarkson, 1995; Kok et al., 2001; Schiebel and Pochtrager, 2003). In exploring the decisionmaking processes of an organization the term stakeholder includes everyone with an interest (or "stake") in what the entity does. Stakeholder theory takes into account the interests of any group or individuals (e.g., stakeholders) who can affect or be affected by the organization's goals (Freeman, 1984).

The ASU experience described herein demonstrates how stakeholders' hierarchal levels and socialization in the organization impact the way they receive and address the adoption of a service innovation. In top strategic organizations - large or medium size firms such as ASU innovation is a strategic task that is guided by top management and involves many individuals and departments in the innovation process (Sundbo, 1997, 2000). From a strategic perspective, adopting a CRM technology solution goes beyond simply providing an information technology solution and building a customer information database - it requires new organizational processes in which management redefines who and what is really important (Fan and $\mathrm{Ku}, 2010)$. 
Analyzing the strategic actions an organization takes in response to stakeholders involves integrating stakeholder and institutional theory (Oates, 2013).

\section{Methodology}

An exploratory, qualitative case study methodology was deployed to investigate the cultural adoption of a technological strategy. Case study methodology is important to gaining deeper insight into a phenomenon (Eisenhardt, 1989; Eisenhardt and Graebner, 2007), and was used to gain access to critical data during a specific time period at the university. Since the aim was to contribute to both practice and theory, an extreme case was sought (Pratt et al., 2006). The athletic department at ASU, a highly bureaucratic environment, was selected as the research setting (Hutchinson and Bouchet, 2014). Yin (2003) notes "the case study method allows investigators to retain the holistic and meaningful characteristics of real-life events" (p.2), while exploratory analysis can be used to uncover multi-dimensional impacts and unanticipated patterns in the data (Berg, 2009). A multi-level approach examines the interconnectedness between the organization and its stakeholders (Chandler and Vargo, 2011; Witell et al., 2015).

\subsection{Data Sample and Collection}

The initial step of data collection consisted of an email sent to athletic department personnel and university employees who had played a role in the CRM adoption and implementation process.

This email asked if they would be interested in participation in either a face-to-face or telephone interview and promised confidentiality. Semi-structured interviews allow for understanding participants' experiences (Rubin and Rubin, 1995; Yin, 2003). The interview questions were developed from the service innovation literature and guided by institutional (DiMaggio and Powell, 1983) and stakeholder (Freeman, 1984) theories. One of the authors conducted ten indepth, semi-structured interviews, which allowed the interviewees to expand upon initial 
questions such as: "Why did you choose to go with a CRM technology solution?" "Who were the key stakeholders influencing the decision to adopt a CRM solution?" "How did the stakeholders engage with other stakeholders throughout the process?" "What are the challenges to the adoption of a CRM system?" "What is the future for CRM?" The interviewing author was also an employee at the university during the adoption and implementation process - this is critical given that interviews are influenced by the rapport established in that context (Lincoln and Guba, 1985). In addition, the interviewing author maintained a reflective journal of his experiences. Interviewees were selected based on their special knowledge or expertise and their active role in the implementation and management of the CRM solution at ASU. Interviews were conducted with four full-time athletic department administrators, two former graduate assistants who worked with the CRM solution, one season ticket holder who used the CRM system, and two company representatives that supply CRM technology to sport organizations. One interviewee asked that their interview be used strictly for background purposes. This request was granted. The length of the interviews ranged between 30 minutes and one hour. Each interview was transcribed and sent to the interviewees for verification of accuracy.

\subsection{Data Analysis}

Consistent with Creswell (2003) and Strauss and Corbin (1990), open, axial, and selective coding were used to analyze the data. Open coding was used during the initial stages of analyses by organizing the data into preliminary codes. Based on recommendations from Miles and Huberman (1994), some codes were assigned a priori based on the literature on service innovation, institutional (DiMaggio and Powell, 1983), and stakeholder (Freeman, 1984) theories, while others emerged from the data. For example, several of the open codes included: organization situational context, dominate logics, stakeholder engagement (formal versus 
informal), and organizational commitment to change. After the open coding process, preliminary codes were organized into axial codes (Neuman, 2006). In the last stage of analysis, selective coding was utilized to identify quotes that best represented the axial/conceptual codes (Creswell, 2003).

In qualitative research, a study is deemed to have trustworthiness if it has credibility, transferability, dependability, and confirmability (Lincoln and Guba, 1985; Schwandt, 2007). Credibility was achieved through the triangulation of the data which included member checks and interviewee feedback regarding the transcripts. The ethnographic reflective journal served to insure transferability. Specific attention was paid to the triangulation of the data. Because one of the authors was uniquely involved in the process special effort was made to ensure the accuracy of the data. These techniques help increase the confidence in the results of the data collection and lessened the chance of bias (Fielding and Fielding, 1986). For dependability and confirmability, the authors not involved in data collection served as auditors and reviewed all data (Erlandson, 1993). Lastly, a peer debriefing was conducted with a senior product manager who specializes in enterprise information systems and their implementation in large public institutions - this individual reviewed both the findings and conceptual model. Peer debriefing allows a peer to audit with the purpose of "exploring aspects of the inquiry that might otherwise remain only implicit within the inquirer's mind" (Lincoln and Guba, 1985, p. 308).

\subsection{Research context: Historical background and marketing challenges faced by ASU}

ASU has an enrollment of over 72,000 students, spread among four campuses in the Phoenix area, and has the largest enrollment of any public university in the United States. ASU's athletic teams, known collectively as the Sun Devils, compete in Division I of the NCAA and are members of the Pac 12 conference. In addition to ASU, the Pac 12 conference consists of the 
Universities of Colorado, Utah, Arizona, Oregon, Washington, California (Los Angeles and Berkeley), Washington State, Oregon State, Stanford, and the University of Southern California. ASU's athletic tradition can be tied to the success of the football program in the 1960 s and 70 s. Under the leadership of Hall of Fame coach Frank Kush, the program enjoyed success at annual bowl games and obtained national rankings.

Kush's retirement in the early 1980s ushered in new challenges, which coincided with a period of transition for ASU due to the influx of new residents into the Phoenix area. These new residents had few or no ties to the school or its athletic programs. In the 1990's, the athletic department struggled with budget deficits and poor performances by its teams. The deficits were blamed primarily on lagging attendance at football games. In addition, the Phoenix Suns (National Basketball League), Arizona Diamondbacks (Major League Baseball), Arizona Cardinals (National Football League), and the Phoenix Coyotes (National Hockey League) moved into the Phoenix area and provided increased competition for entertainment dollars. As a consequence, the role of the ASU athletic department's marketing team became critical to the athletic programs' financial success. According to Lee et al. 2009 when competition is intense, innovation often becomes the means for firms to maintain or gain their competitiveness. The marketers needed to find a way to meet the wants and needs of sport fans in the greater Phoenix area more effectively and efficiently than the competition.

Given the associated risks due to the changing environment and growing competition, the school's athletic department faced the challenge of marketing to sports fans in Phoenix, while dealing with a limited marketing budget. Risk often sparks innovation which is one dimension of service innovation that deserves more scholarly attention (Witell et al., 2015). Athletic department personnel felt that the days of mass marketing their product were over, due to their 
limited budget and the intensely competitive sports environment in Phoenix. Unlike some Division I athletic programs, ASU's athletic department competes directly with professional sports teams that have enjoyed a high level of success over the last decade. The Arizona Diamondbacks, for example, won the 2001 World Series, and the Arizona Cardinals played in the Super Bowl in 2009. As a result of this competitive environment, the university mandated that the athletic department administrators find a solution or solutions to these marketing challenges. In addition, the arrival of Gene Smith as athletic director in 2000 brought a sense of urgency regarding revenue generation. New leadership often brings new agendas (Cousens and Slack, 2005; O'Brien and Slack, 2004) facilitating the erosion of dominant logics and laying the groundwork for change (Welty Peachey and Bruening, 2011).

The primary marketing goal of the ASU athletic department is to meet the wants and needs of new and old sport fans, in order to increase revenue. Similar to any nonprofit organization, the ASU athletic department needs to generate revenue, which is achieved through a variety of revenue streams, including ticket sales, sponsorships, donations, television contracts, and concessions. The athletic department, however, has direct control of only one of these revenue streams, ticket sales. The PAC 12 conference controls television revenue, and ASU outsources its sponsorship and concessions to third party vendors. Thus, ticket sales remain the dominant revenue stream over which ASU has direct control, which means that the athletic department must constantly strive to increase ticket sales. Ticket sales account for approximately $38 \%$ of the athletic department revenue (personal communication, 2012). This means that the athletic department must find better ways to manage the information regarding season ticket holders and individual ticket sales. 


\section{Findings and discussion}

The interviews revealed that there were both benefits and challenges regarding ASU's adoption of a CRM technology solution. The assumption is a CRM solution linked to a service product that is innovative will lead to enhanced financial performance, customer satisfaction, and reputation (Cheng and Krumviede, 2012; Christofi et al., 2015; Zhou et al., 2005). However, successful implementation is not cheap, fast, or easy (Dickie, 1999), nor is it guaranteed, as failure is the norm for the majority of new service offerings (Gourville, 2006). The main benefit to adopting service technology, a CRM solution, was generating incremental revenue, which resulted from capturing better data and the opportunity for better personalized marketing. ASU also encountered five major challenges for implementing service innovation: a) coordinating adoption; b) obtaining commitment (buy-in); c) developing competency; d) estimating costs; and e) developing content.

\section{1 Benefits of a Technology Service Innovation}

\subsubsection{Generating incremental revenue}

To fully utilize the service technology ASU's athletic department personnel wanted to augment their CRM strategy with a commitment to generate revenue by implementing a full-service aggressive ticket sales department. The organization understood that adopting a service technology solution would likely fail without an integrated approach to technology, processes, and people. One of the biggest mistakes an organization can make is to under commit to the service innovation initiative (Dickie, 1999) by not allocating a bundle of resources - human, technological, and organizational (Gadrey et al., 1995) to address and make the changes required across the service ecosystem (Kindström et al., 2013; Dominguez-Péry et al., 2013; Su, 2011). 
Senior management at ASU realized adopting a service technology required redesigning

the sales process. This new ticket sales department would consist of an Assistant Athletic

Director of Ticket Sales and eight to 10 part-time employees devoted to season and group sales.

An ASU employee stated: "It should be mentioned that dedicating resources to a sales

department is very unusual at the college level. This is really more of a professional sports

model, but we are in Phoenix where we have to compete with the professional sports teams for

entertainment dollars." Research suggests that service innovation advances the creation of

sustainable advantage by enabling a company to offer superior value in contrast to competitors

(Salunke et al., 2013). ASU personnel were hoping that service technology would allow the

athletic department to effectively handle customer acquisition, retention, and development.

According to an ASU employee, soon after the implementation of the technology a dedicated

sales force was hired to capture the value from the service innovation, which "drove sales

beyond our expectations." By utilizing CRM technology the sales force could target specific

demographics of fans, and thus, generate additional revenue. An employee noted: "Advertising

in Phoenix is expensive, CRM allows us (athletic department) to specifically target our

demographics. That helps us increase revenue and decrease advertising dollars."

\subsubsection{Capturing Data}

Another key benefit ASU derived from the technology service innovation was the ability to

capture data from its various interactions with customers. Service innovation forms value

creation and plays a major role in facilitating the interaction between an organization's services

and services sought by the customer (Mizik and Jacobson, 2003; Möller et al., 2008). One senior ASU administrator stated: "Until we adopted CRM, we knew very little about our customers. In that way, college athletic departments are different than for-profit firms. A big part of the value 
of CRM was it lets us capture data which allow us to understand our customers better." The technology service innovation helped the athletic department systematically sort and organize the data that were gathered. The system allowed the department to build a database for customer information that described relationships in detail—sales personnel could then access this information to try to match the customer needs with products offered. Cheng and Krumwiede (2012) illustrated a positive relationship between service innovation and customer orientation. One senior administrator stated that the biggest benefit of implementing a CRM technology solution is that it would "allow the organization to get the knowledge out of the sales rep's head and into a centralized database where it can be retrieved if that sales rep leaves the organization." Thus, CRM allows the athletic department to maximize value for stakeholders by taking stakeholder (customer) interests into account and building stronger relationships with them (Freeman, 1984). Essentially, the technology service innovation gave ASU the ability to better understand its target audience.

ASU's CRM content strategy revolved around utilizing the Devil's Domain, the online fan club accessed via the ASU athletic department website. Devil's Domain is used to collect basic information from Sun Devil fans, including birthdays, ticket purchasing preferences, and favorite ASU sports. In exchange for this information fans get free access to the Devil's Domain portal, ticket and merchandise discounts, newsletters, and exclusive video highlights. Subsequently, a study conducted by the athletic department found that $85 \%$ of fans described themselves as "very satisfied" with the Devil's Domain. A service innovation can improve the service delivery to positively affect customer satisfaction (Danjum and Rasli, 2012). The data generated via the Devil's Domain helped the athletic department market its product in two 
critical ways. First, the athletic department better understood where its marketing dollars needed to be allocated. Second, ASU used the information to better position sales efforts.

The implementation of the service innovation was conducted in conjunction with the athletic department making a commitment to hiring a Director of Ticket Sales and a sales staff. One employee shared: "Understand, the whole thing was based off of adopting CRM and hiring a sales staff. In order to justify the expenses we had to show the impact on sales." The two decisions served to complement each other. First, the decisions sent notice to both internal and external critics that ASU's athletic department was serious about generating revenue with the goal of becoming self-sustaining. Second, increased staffing allowed the athletic department to actively solicit potential clients and provide information to current ticket holders.

\subsubsection{Opportunities for personalized marketing}

CRM allowed the athletic department to establish bonds between the brand and its customers. Having access to data allows organizations to improve their customer response by offering personalized campaigns (Neslin and Shankar, 2009), which then builds stronger relationships with stakeholders to maximize value (Freeman, 1984). Personalization focuses on building a meaningful one-to-one relationship with each customer by understanding his or her needs and helping him or her satisfy those needs efficiently and effectively. According to Parvatyar and Sheth (2001), CRM and relationship marketing are terms which are often used interchangeably. Relationship marketing shifts the focus of the marketing exchange from transactions to relationships (Rowley, 2005), while a CRM solution allows companies to market their products in a more personalized manner.

An advantage of personalization is increased consumer lock-in which decreases a consumer's propensity to switch after an initial investment has been made (Zauberman, 2003). 
By utilizing the technology service innovation, ASU athletic department personnel could target specific demographics of fans and notify them by email of special offers. In the first year (20042005) utilizing CRM, for example, the athletic department extended an exclusive ticket offer to all members of the Devils Domain for the annual ASU/University of Arizona basketball game. The offer brought in $\$ 14,000$ in the first 48 hours (Berkowitz, 2004).

The technology service innovation also helps sponsors by giving them direct access to fans. For example, this access could be in the form of a coupon emailed directly to a certain demographic of the fan base. CRM enables ASU to regularly communicate with the team fan base, increasing their involvement, trust, and loyalty to the team, and building a strong longitudinal relationship (Tsiotsou, 2013). An ASU Assistant Athletic Director noted that these ticket offers typically see a $3-11 \%$ response rate and stated that:

.. . by combining offers with exclusive content we've been very successful; a lot of people who get e-mail marketing just delete it. But because we send content, our fans read it, enjoy it, and view the offers as a special benefit of being part of the Devils Domain. They don't see it as advertising; they see it as a reward for membership. Finally, at most universities, fundraising is tied to ticket sales. Essentially, the better the location of the seats the more one is asked to donate. The more tickets one sells the more revenue is raised via donations.

\subsection{Challenges to CRM implementation}

\subsubsection{Coordinating adoption}

Although technology service innovation can result in many benefits, it comes with varied challenges. One of the central challenges of utilizing a technology solution within a university's athletic department involves the coordination of activities across athletic department and 
university lines. Critical to a successful implementation is managing the socially complex service ecosystem at the micro, meso, macro levels (Chandler and Vargo, 2011; Witell et al., 2015). Most professional sports organizations (for-profits) have their service technology systems directly tied into both the ticket sales and ticket operations departments. Intercollegiate athletic departments, however, typically have separate reporting lines for ticket sales and ticket operations. One administrator noted: "Coordination and reporting lines are always going to be a problem in athletic departments where departments are siloed. I'm sure for-profit companies have silo problems as well, but they have a profit motif as an incentive to come together. In college athletics we don't have this." The culture within an organization can affect information processes (Sinkula, 1994), impacting employees' motivation to either move toward a new service or stay committed to an existing system (Janssen, 2003).

Another challenge centers upon which department within athletics should be charged with overseeing the service innovation. Sheth (2002) discusses the challenges of who is in charge of a technology service innovation implementation, and Sok and O'Cass (2015) emphasize the critical role of employee empowerment to the delivery of service innovation. Typically, in intercollegiate athletics, an external relations office oversees any revenue that relates to ticket sales. For a technology solution to work effectively, however, there must be a good relationship between whoever is overseeing the CRM system and the ticket operations department. At ASU, the technology service innovation was overseen by an Assistant Athletic Director of Revenue Generation, who answered to the Senior Associate Athletic Director for External Relations, who also oversaw ticket operations at the school. However, this was a unique arrangement. Allocation of resources - human, technical, and organizational (Gadrey et al., 1995), combined with employee empowerment is a critical strategic focus in achieving 
service quality through service innovation (Sok and O'Cass, 2015). At most schools the ticket operations department reports to finance/operations and ticket sales reports to external relations.

The final challenge to overcome involves the mindset of intercollegiate athletic departments against ticket sales. This mindset may be a byproduct of several factors, including that fact that universities generally cover any cost overruns by athletic departments. In addition, revenue generation is seldom tied to university evaluation and reward systems (e.g., "not part of my contract"). Therefore, there is often little incentive for athletic department personnel to enhance revenue via ticket sales. The implementation of a service innovation is complex as it can affect employees' roles and require significant changes in behavior (Sok and O'Cass, 2015). Thus, one of the main risks of service innovation is the "business as usual" attitudeisomorphism and dominate logics (Cousens and Slack, 2005; DiMaggio and Paul, 1983) of internal stakeholders. Currently, very few athletic departments have full-time dedicated sales staffs that focus on increasing season ticket sales. Regarding this, one staff member said: "Ticket sales is tough work that few employees in the athletic department want to be bothered with. When it comes to getting promoted to an athletic director's job, experiences with donors and fundraising is critical. Ticket sales, not so much."

Specifically, the coordination challenge ASU faced centered on how to integrate a technology service innovation between ticket operation, ticket sales, and the alumni relations departmental staffs. Each of these stakeholders operates independently, with different priorities, structure, and operations. This independence is a major barrier to service innovation implementation and efficiency. One mid-level marketing employee in the athletic department noted: 
A system needs to integrate with your ticketing (operation) system and donor system so that your donor/tickets notes are all in one place. Very few systems do this and the ones that do cost a fortune. In an ideal world, you would have three-way, bi-directional feeds between your ticketing system, your donation system, and your CRM system. Otherwise, you're left to manually import data from ticketing and donor software onto the CRM system, and the reality is that doesn't often happen.

A major problem ASU faced involved integrating the athletic department's technology solution with the university's alumni relations department. The relationship between these two departments is critical, because the alumni relations department is the primary point of contact between the university and many of its stakeholders. One athletic department employee noted that "most athletic departments don't have access to alumni data directly. That information is usually guarded like Ft. Knox." Another senior level athletic department employee stated that "we are lucky here (ASU). . . There is a good working relationship between all the departments on campus, but I've been at other schools where that is not the case." Employees engaged in the delivery of the service innovation "operate in a boundary spanning role between the firm and its customers and are intimately involved in the implementation of the firms' strategic initiatives, serving as either catalysts for or barriers to new service development or service improvements" (Sok and O'Cass, 2015, p. 140). In order for a service innovation to be successfully adopted within a bureaucratic setting, it is imperative for all personnel within the organization to "buy in" to the concept.

\subsubsection{Obtaining commitment (buy-in)}

Athletic department personnel knew that in order for the service innovation to be successful, they needed a commitment from the various stakeholders, those both affected by and affecting the 
change (adoption of a CRM strategy) (Freeman, 1984). A service innovation can be perceived by internal stakeholders as either promoting their well-being or challenging it (Witell et al., 2015). The stakeholders included the athletic director, season ticket holders, and coaches. This proved difficult due at least in part to the general segmentation (both psychologically and physically) of a college campus. As Payne and Frow (2005) note, "CRM can fail when a limited number of employees are committed to the initiative; thus, employee engagement and change management are essential issues in CRM implementation" (p.167). In essence, the athletic department must strive to overcome dominant logics of action (DiMaggio and Powell, 1983) concerning traditional marketing tactics in Division 1 athletics in order for an effective CRM system to be implemented. For example, one ASU Assistant Athletic Director explained that "CRM systems are vitally important but only if the athletic department is committed to giving them the resources and support necessary to succeed." Another athletic department administrator said:

This commitment needs to come from both upper and lower management. It is essential for both executives running the organization and the sales and service representatives to buy in and understand the benefits of a CRM strategy. It will not be successful if only one of these thinks it's great but the other one doesn't.

Another senior level executive added:

The process in deciding whether or not to invest in a CRM initiative is significant; therefore it is essential that the organization as a whole has bought into the idea of database marketing. Unlike some departments that operate autonomously, a CRM strategy relies on numerous departments being able to communicate to be effective. 
Thus, as can be seen, obtaining commitment within a higher education setting is particularly challenging due to the decentralized nature of a college campus.

The ASU experience illustrates how the informal system among stakeholders produces intrapreneurship — the act of behaving like an entrepreneur while working within a large organization. An intrapreneur is an employee who enables organizational change by assuming or being granted direct responsibility to create, discover, and implement new ideas, opportunities, and innovations for the organization. Employee empowerment, a proactive orientation in which employees expect that they can influence organizational activities and decisions (Spreitzer, 1995), enhances a firm’s service innovation and service quality (Sok and O’Cass, 2015). However, the process is guided by the management system and the culture of the institution (Sundbo, 1997; 2000). According to institutional theory (DiMaggio and Powell, 1983), these changes are very difficult to implement consistently over the long term, due to dominant logics of action. These dominant logics need to be broken down, and then rebuilt with a new logics of action (DiMaggio and Powell, 1983; Cousens and Slack, 2005). Sometimes, it is new actors, such as an intrapreneur, who will be best positioned to lead and guide this change (DiMaggio and Powell, 1983).

\subsubsection{Developing competency}

Although having a systematic way of sorting the data compiled by the athletic department would be beneficial to ticket sales, a technology service innovation is effective only if stakeholders are able to operate it. Professional sports organizations tend to be more advanced in their use of service technologies than their college counterparts. This is a byproduct of complicated university reporting lines and a lack of technical knowledge available in athletic departments. A professional sports organization, which by definition is a for-profit firm, can hire a long-term 
employee exclusively to oversee the service innovation initiative. However, an executive that has worked in both college and professional sport organizations stated that hiring a long-term employee to specifically oversee implementation of a service technology is more challenging within an intercollegiate athletic department, where typically there is less latitude to pay salaries needed to hire potential employees. The employee hired needs to able to bridge the gap between the technical aspects of the software and the sales-related function of the system. In addition, the employee needs to have a key understanding of the main function of the system, which is to increase sales and service. ASU officials were in agreement that if you invest in a system, you must invest in a person (or department) to operate it. All institutions struggle with balancing capacity — the amount of work the employees can do — with the amount of work the organization needs to complete. As employee head count is always an issue within intercollegiate athletics that could present a problem.

Dominant logics (DiMagio and Powell, 1983) in intercollegiate athletics suggest that within athletic departments there is often a reluctance to pay competitive salaries to noncoaching personnel. This was true at ASU regarding the position overseeing implementation for the service technology, the CRM solution. ASU relied on graduate assistants to handle many aspects of the marketing function. By the time the graduate assistants figured out the intricacies of their job their assistantships had expired. ASU learned that a CRM technology solution would require a more dedicated, long-term level of service. Another area of concern is whether or not an athletic department can get athletic department employees on board with the service innovation initiative, and can the department marshal key stakeholders at the university to support CRM? This was a constant struggle at ASU. One of the ways that ASU thought it could support a CRM solution was to dedicate a website with original, exclusive content specifically 
for ASU fans. This website would serve as an added value benefit to season ticket holders. If value can be maximized for various stakeholder groups (athletic department employees, season ticket holders and other fans, university administration), then implementation of a change process such as adopting a service innovation may go more smoothly (Freeman, 1984).

\subsubsection{Estimating costs}

As with any new technology, cost is a critical issue. Implementing a technology solution can be costly and requires skilled workers who can navigate the system. Implementing a service innovation is a long and expensive process. Thus, costs need to be measured against the benefits when deciding whether or not a service innovation is right for a particular organization. Since ASU was the first intercollegiate athletic department to implement a CRM technology solution, getting an estimated cost was difficult. However, athletic department personnel estimated that there would be initial costs of $\$ 20,000$ and another $\$ 25,000$ to $\$ 30,000$ needed annually to maintain the system (Berkowitz, 2004). The fact that ASU was the first athletic department to utilize CRM could initially be viewed as a negative, but there was also an advantage - the institution was able to negotiate a competitive price on the theory that if it was successful ASU would recommend the system to other schools. One former ASU employee stated that "CRM can't be a flash in the pan idea because the benefits will not be reaped in the first year." The organization needs to allot time to decide on a system, implement that system, and reap the rewards of this approach. Another ASU Assistant Athletic Director stated:

Organizations need to take their time and make sure that they have a good understanding about the front end cost of CRM. Since we were the first athletic department to go to a CRM system we didn't have the benefit of calling around to other teams and asking how they got started. The schools and teams that come after us have a huge advantage. 
It is critical for a sport organization to ascertain a way to estimate the cost of not only purchasing a service technology, but also for the cost of implementation. As first movers, ASU was challenged to determine all of the potential costs without being able to refer to other athletic departments.

\subsubsection{Developing content}

Finally, ASU's athletic department staff noted that a CRM system is only as good as the content provided and can take years to build. Content needs to be current and provide accurate, detailed information so that users will want to consistently visit the website. Several athletic department employees noted that this could be where ASU struggles regarding CRM. One mid-level athletic department employee stated:

For CRM to be successful you need content that people want to view. Unfortunately, at ASU [and other schools], that means dealing with the coaches from the individual sports. You need their permission to interview players, assistant coaches, etc. That's tough to get. Too often administrators are reluctant to push coaches to cooperate.

This strategy had mixed results. While fans liked having access to the exclusive Devil's Domain, getting coaches and administrators to grant exclusive interviews proved problematic. There was resistance to change on the part of ASU's coaches regarding making players and themselves available for interviews and video segments. And, the athletic department and the university were reluctant to provide exclusive information to just one media outlet. This in turn made the Devil's Domain less exclusive. In this case, individuals may not have felt that the new CRM system would result in direct benefit to them, or could even negatively impact their areas of responsibility, thereby leading to resistance to the change (Welty Peachey and Bruening, 
2011). Athletic departments are rooted in tradition, and these dominant logics are extremely difficult to change (DiMaggio and Powell, 1983).

James Ward, Professor of Marketing in ASU's W. P. Carey School of Business, cautioned that a CRM system's effectiveness depends a great deal on the size and quality of the fan database, as well as on how the organization uses it (Knowledge, 2005). For instance, once a database is built, organizations can be tempted to overuse the system for short-term sales gains (Knowledge, 2005). This overuse often occurs by pushing too many offers and communications to fans. One athletic department Marketing Manager noted:

This content needs to be up-to-date information that the end user can't get elsewhere. This often leads to potential problems in college athletics where coaches typically control access to players, etc. This can lead to problems with mainstream media that is also interested in gaining access to real-time information.

The idea of owning the content that one creates is a unique concept for athletic departments. For years the dominant logics and basic assumptions within college sports was that universities put the product on the field, networks broadcasted the games, and the local news covered the highlights. However, this model is increasingly coming under pressure as athletic departments are realizing the value that they can harness by owning the content they produce, essentially forming a new dominant logics of action regarding effective marketing strategies (DiMaggio and Powell, 1983).

Slowly, some dominant logics regarding operations and administration of intercollegiate athletics are eroding. Perhaps this is due to the limits of most athletic departments' revenue models which consist of ticket sales, sponsorship sales, and television rights fees. In essence, college athletic administrators are learning that all the "low hanging fruit has been picked". As 
the costs of sponsoring Division I athletics continue to escalate, athletic departments must continue to strategize how new service innovations can raise revenue.

\section{Practical implications}

In referring back to our original research questions, the purpose in presenting ASU's experience was to highlight the benefits and challenges associated with an organization's decision to adopt service innovation. Isomorphic pressures (DiMaggio and Powell, 1983) on institutions and stakeholders within the service ecosystem make resistance to change a norm. However, "business as usual" is challenged by the external environment and growing consumer expectations for the firm to create value through innovation (Lee et al., 2009; Parris, 2013). While there are limits on what can be learned from a single situation, this case study provides insight into how an organization can overcome dominant logics to implement a service innovation.

\subsection{Implementation steps for practitioners}

Even though service innovation is not a new concept (Miles, 1993) and technology plays a large role in these innovations (Dabholkar, 2000; Drennan and McColl-Kennedy, 2003; Timmor and Raymon, 2007; Wünderlich et al., 2015) there is a paucity of research that helps service marketers and management to ideate and pinpoint core management issues associated with integrating technology in a service ecosystem (Guastafsson et al., 2015). The case study presented could, and indeed, should be used by any organization exploring the possibility of adopting a service technology. Four recommendations are drawn from this study. Service marketers and management should: 1) make a long-term commitment to service technology as an analytical tool to engage customers in the organizational culture that allows customers to interact with the organization, not just as a tool for short-term sales; 2) ensure that the organization has 
the technical capabilities to fully utilize the technology; 3) work hard to obtain commitments from all stakeholder groups and realize that a commitment from the top does not necessarily mean a commitment from everyone; and 4) pursue a carefully crafted series of steps to implement a service innovation.

Suggested implementation steps. Successful adoption and implementation of a service innovation requires that the organization go through a series of implementation steps, such as the following:

1) Select a preliminary champion for the service innovation. Someone must be able to articulate the potential benefits of the service innovation, implementation challenges, and sell the idea to a broad array of stakeholders at all levels of the service ecosystem: individual (micro), organizational (meso), and societal (macro) (Chandler and Vargo, 2011; Witell et al., 2015).

2) Learn about service innovations and their potential benefits. This knowledge is critical for preparing the necessary persuasive proposal.

3) Compare the service innovation's potential benefits with desired improvements. Essentially, determine what the organization needs done and compare that with what the service innovation can do.

4) Develop a persuasive proposal, with emphasis on cost/benefits. Without a solid proposal, the necessary buy-in, commitments, and "backstopping" will not occur. A proposal should be written that covers all details, and be able to be delivered in a short "elevator speech.”

5) Ensure executive sponsorship and commitment. Successful implementation absolutely must have support from higher levels of the organization, starting with the Executive 
Suite, all relevant Vice Presidents, Directors, and so on. An executive supporting the project has the ability to help overcome various kinds of resistance.

6) Hire a project manager and empower personnel. Someone must be directly accountable, and it may not be the initial champion. These employees must be technically proficient, fan-focused, and relationship builders.

7) Select implementation partner. The implementation partner is the software vendor.

8) Define the key performance indicators that will measure the project success. The desired outcomes should be formulated into key performance indicators so that service technology performance can be better evaluated.

9) Consider launching in phases. Implementers should break down all of the activities needed and phase them in over time.

Following these suggested implementation steps to adopting a service technology will help service organizations develop a proactive strategy - a game plan — to address the potential pitfalls and barriers experienced by ASU.

\section{Theoretical implications: Conceptual model for likelihood of implementation success}

Integration of the findings led to a conceptual framework for describing the likelihood of a service technology's successful implementation across a wide range of organizations based upon the interaction of the strength of key actors, organizational situation perception, and organizational commitment. This conceptual framework starts with the search for a service innovation by key actors in the organization as a reflection of either the risk of losing revenue, the opportunity to increase revenue and customer satisfaction, or both. Next, key actors engage, assess, evaluate, and coordinate across the organization and all stakeholders to test assumptions and gain buy-in. The model ends with the role of critical stakeholders and organizational 
interactions that impact the likelihood of the implementation reaching one of three outcomes: 1) full implementation, 2) partial implementation, and 3) failed implementation (See Figure 1).

Insert Figure 1 Here

\subsection{Search for service innovation}

Given organizational dominate logics of action and resistance to change, especially in a bureaucratic setting, adoption of a service innovation is precipitated by the perception among key stakeholders that there is a real risk of losing revenue and decreasing customer satisfaction, that there is an opportunity to increase revenue and increase customer satisfaction, or ideally both. "Business as usual" is challenged when the competitive environment requires a greater responsiveness to the market and a stimulus for the firm to innovate (Lee et al., 2009; Sok and O’Cass, 2015). Risk plays a critical role in fostering change, which is one dimension of service innovation that deserves more scholarly attention (Witell et al., 2015).

Generally, change occurs slowly in bureaucratic organizations- resistance to change is the norm (Welty Peachey and Bruening, 2011; Hutchinson and Bouchet, 2014). Thus, significant pressure must be present to instigate the change process, and the identification and formal recognition of the key actor(s). The erosion of dominant logics of action serves to increase field-level change (Cousens and Slack, 2005). The key actors are the intrapreneurs who have assumed or been tasked with improving the status quo, guided by the management system and the culture of the institution (Sundbo, 1997; 2000). Employees can be driven to support or resist the process of innovation (Janssen, 2003), and their perceived empowerment can significantly influence organizational initiatives, such as adopting a service innovation (Sok and 
O’Cass, 2015; Spreitzer, 1995). Lastly, the key actor(s) must search for, review, and select the service innovation.

\subsection{Assessment-Evaluation-Coordination}

With the service innovation identified, the key actor(s) must engage across the formal and informal power structures of the organization to test "whether, why, and how" to implement the innovation (Markus and Tanis, 2000, p. 189). Formal power centers are represented by the assorted departments, directors, and leaders from whom resources will be utilized in the implementation and ongoing support of the service technology. Service innovation requires new processes and ways of communicating across the entire service ecosystem, which impacts stakeholders at the micro, meso, and macro levels (Chandler and Vargo, 2011; Witell et al., 2015). The success of the key actor(s) in this process is dependent on the institutional power the key actor has marshaled to engage the assorted stakeholders, and is why support from the top of the organization is essential. The key actors will engage along formal communication channels to: 1) validated the technology selection, 2) ensure the proposed solution fits the customer needs of today, 3) evaluate the strategic differentiation possible through implementation of the technology solution, and 4) assess the organization's capabilities of delivering the proposed solution. Failure to complete this formal validation process leaves the key actor(s) vulnerable to implementing a solution that either fails to meet organizational needs, cannot be implemented by the organization, and/or fails to meet customer needs.

Simultaneously, the key actor(s) must engage the informal power centers to generate buyin among team members who will be responsible for actually carrying out the work. These conversations and changes involve the risk factors which drove the organization to assess service innovation, and a potential underlying concern among front-line team members is the perception 
they have not/are not doing their job well. Thus, their potential concern about the new change is that it could mean losing their jobs, which would likely generate resistance to the change. Additionally, with the adoption of a technology solution, metrics associated with the effectiveness of individual roles makes each team member's contribution more apparent to everyone within the organization. For many, this visibility can feel like a threat or a direct incursion into their autonomy. At this level, organizational power is not persuasive, and the key actor(s) ability to engage with employees and influence them on a personal level will determine the effectiveness of the service innovation implementation.

These actions will occur across the functional areas of the organization; however, different functional areas will have greater or lesser direct involvement or individual employee exposure than others. Specifically, the information technology and service teams will have the greatest amount of work to complete as part of the service innovation and processes implementation while the sales and marketing functions will have the most to gain. As a result, the key actor(s) must leverage a combination of formal and informal engagement tools to bring all functional areas into alignment.

\subsection{Critical stakeholder and organizational interactions}

The interplay between the strength of the key actor(s), organizational situation perception, and organizational commitment to service innovation will dictate whether the service innovation implementation is fully implemented. Strength of key actor(s) measures how well the key actor(s) manage the formal and informal assessment, evaluation, and coordination tasks. Organizational situation perception measures the perceived consequences/opportunities of nonaction/action. Consequences and opportunities result in varying implementation outcomes. Organizations weigh consequences more heavily than opportunities-resulting in greater 
organizational engagement (erode dominate logics) when risks are dire, than when opportunities are great. The strength of the key actor(s) and organizational situation perception combine with organization commitment to determine the implementation outcome.

Organizational commitment can best be represented by the resources allocated to the implementation. Full dedication of resources and staff can successfully migrate small or large complex historical data/legacy processes, whereas low dedication of resources and staff will not be successful in migrating historical data/processes. A mitigating factor to resource commitment is the value placed on historical data and/or legacy processes. If these data sets and processes are perceived as low value, than an implementation can move forward without incorporating them, freeing stretched resources to focus elsewhere. However, if they are perceived as mission critical and resources are not allocated to manage their migration, this can lead to a failed implementation.

\subsection{Propositions for implementation success}

The combination of the strength of key actor(s), organizational situation perception, and organizational commitment are utilized to propose 36 relevant propositions (see Figure 1). Touted failure rates for service innovation implementation range from 55\% (Rigby et al., 2002) to $63 \%$ (Prezant, 2013). Although the conceptual framework aligns with these failure rates with $53 \%$ ( 19 out of the 36 propositions) failing, this is due to the framework being representative of the probability based on the listed factors combining in practice. ASU's successful implementation was a result of strong key actors, severe consequences of non-action paired with significant opportunity to increase revenue and improve customer satisfaction, with full dedication of resources, despite high perception of value for historical data and processes. However, successful implementations are not the norm. 
The conceptual framework can serve as a visual tool for practitioners to evaluate the likelihood of implementation success, as well as stimulate scholars to test the propositions advanced. The model extends the proposed duality of service innovation outcomes as either success or failure (Witell et al., 2015) to acknowledge the likelihood of a partial implementation where marginal success is achieved. This study addresses gaps in the service innovation literature and can help service marketers and management navigate socially complex service ecosystems (Carlborg et al., 2014) and their intersecting and overlapping multi-level effects (Chandler and Vargo, 2011) to pinpoint core management issues in integrating a new technology (Gustafson et al., 2015) and overcome barriers to service innovation. The conceptual framework is a starting point to build knowledge regarding service innovation, as Hambrick (2007) states "theories are not ends in themselves" (p. 1346).

\section{Conclusion}

Implementing a service innovation has allowed companies in various industries to target specific customers within the marketplace who would be receptive to purchasing a designated product. The availability of data will continue to expand as a higher percentage of buying is transacted online. Subsequently, as service innovations technologies advance, data analytics will enable service marketers and managers to better define their consumers' buying patterns.

Understanding these buying patterns will be more important as service organizations learn how to track the spending patterns of consumers' auxiliary revenue. Furthermore, as service innovations through technology advance to combine personalization and customer self-selection (i.e., customization), service organizations will be able to provide personalized-customized hybrid bundles (Parris, 2013) to their customers. Service organizations can utilize service innovations to move customers up the value chain, and generate revenue streams. However, the 
success of the service innovation begins with developing a winning game plan for implementation.

1

2

3

4

5

6

7

8

10

11

12

13

14

15

16

17

18

19

20

21

22

23

24

25

26

27

28

29

30

31

32

33

34

35

36

37

38

39

40

41

42

43

44

45

46

47

48

49

50

51

52

53

54

55

56

57

58

59

60 


\section{References}

Alshawi, S., Missi, F., \& Irani, Z. (2011), “Organizational, technical and data quality factors in CRM adoption-SMEs perspective”, Industrial Marketing Management, 40(3), pp. 376 383.

Araujo, L., and Spring, M. (2006), "Services, products, and the institutional structure of production”, Industrial Marketing Management, 35(7), pp. 797-805

Arora, N., Dreze, X., Ghose, A., Hess, J., Iyengar, R., Jing, B., Joshi, Y., Kumar, V., Lurie, N., Neslin, S., Sajeesh, S., Su, M., Syam, N., Thomas, J. and Zhang, Z.J. (2008), “Putting one to-one marketing to work: Personalization, customization, and choice”, Marketing Letters, 19(3-4), pp. 305-321.

Barcet, A. (2010), "Innovation in services: A new paradigm and innovation model”, In F. Gallouj and F. Djellal (Eds.), The handbook of innovation and services: A multidisciplinary perspective, Cheltenham, Edward Elgar, pp. 49-67.

Bolton, R.N., and Lemon, K.N. (1999), “A dynamic model of customers' usage of services: Usage as an antecedent and consequence of satisfaction", Journal of Marketing Research, 30 (May), pp.171-186.

Berg, B.L. (2009), Qualitative Research Methods for the Social Sciences, 7th ed. Boston: Allan and Bacon.

Berkowitz, K. (2004), “Selling your sports”, Athletic Management, 16(5), August/September

Berry, L.L., Shankar, V., Parish, J.T., Cadwallader, S., and Dotzel, T. (2006), “Creating new markets through service innovation", MIT Sloan Management Review, 47(2), p.56. 
Boulding, W., Staelin, R., Ehret, M., \& Johnston, W. J. (2005), “A customer relationship management roadmap: What is known, potential pitfalls, and where to go", Journal of Marketing, 69(4), pp. 155-166.

Bull, C. (2003), "Strategic issues in customer relationship management (CRM) implementation", Business Process Management Journal, 9(5), pp. 592-602.

Carlborg, P., Kindström, D., and Kowalkowski, C. (2014), “The evolution of service innovation research: a critical review and synthesis", The Service Industries Journal, 34(5), pp. 373 398.

Chae, B.K. (2012), “An evolutionary framework for service innovation: Insights of complexity theory for service science", International Journal of Production Economics, 135(2), pp. $813-822$.

Chandler, J.D., and Vargo, S.L. (2011), “Contextualization and value-in-context: How context frames exchange”, Marketing Theory, 11(1), pp. 35-49.

Cheng, C.C., Chen, J.S., and Tai Tsou, H. (2012), "Market-creating service innovation: verification and its associations with new service development and customer involvement”, Journal of Services Marketing, 26(6), pp. 444-457.

Cheng, C.C., and Krumwiede, D. (2012), "The role of service innovation in the market orientation—-new service performance linkage", Technovation, 32(7), pp. 487-497.

Christofi, M., Leonidou, E., Vrontis, D., Kitchen, P., and Papasolomou, I. (2015), “Innovation and cause-related marketing success: a conceptual framework and propositions", Journal of Services Marketing, 29(5), pp. 354-366.

Clarkson, M.B.E. (1995), “A stakeholder framework for analyzing and evaluating corporate social performance", Academy of Management Review, 20(1), pp. 92-117. 
Coombs, R. and Miles, I. (2000), “Innovation, measurement and services: the new problematique", in Innovation Systems in the Service Economy, Economics of Science, Technology, and Innovation, Springer, US, pp. 85-103.

Cousens, L., and Slack, T. (2005), "Field level change: The case for North American major league professional sport," Journal of Sport Management, 19, pp. 13-42.

Dabholkar, P. A. (2000), “Technology in service delivery: Implications for self-service and service support”, in SWARTZ, T.A. and IACOBUCCI, D. (Eds), Handbook of Services Marketing and Management, Sage, Thousand Oaks, CA, pp. 103-110.

Danjum, I., and Rasli, A. (2012), "Imperatives of service innovation and service quality for customer satisfaction: Perspective on higher education", Procedia-Social and Behavioral Sciences, 40, pp. 347-352.

Dickie, J. (1999), "Why CRM projects fail”, CRM Journal, 1(1) Available at: www.first-wave.net

DiMaggio, P. J., and Powell, W. W. (1983), “The Iron Cage revisited: Institutional isomorphism and collective rationality in organizational fields", American Sociological Review, 48(2), pp. $147-160$.

Dominguez-Péry, C., Ageron, B., and Neubert, G. (2013), “A service science framework to enhance value creation in service innovation projects. An RFID case study", International Journal of Production Economics, 141(2), pp. 440-451.

Drennan, J., and McColl-Kennedy, J.R. (2003), “The relationship between Internet use and perceived performance in retail and professional service firms", Journal of Services Marketing, 17(3), pp. 295-311. 
Eisenhardt, K. M. (1989), "Building theories from case study research”, Academy of Management Review, 14(4), pp. 532-550.

Eisenhardt, K. M., and Graebner, M. E. (2007), “Theory building from cases: opportunities and challenges", Academy of Management Journal, 50(1), pp. 25-32.

Erlandson, D. A. (1993), Doing Naturalistic Inquiry: A Guide to Methods. Sage.

Ettlie, J.E., and Rosenthal, S.R. (2011), "Service versus manufacturing innovation”, Journal of Product Innovation Management, 28(2), pp. 285-299.

Fan, Y. W., and Ku, E. (2010), “Customer focus, service process fit and customer relationship management profitability: The effect of knowledge sharing", The Service Industries Journal, 30(2), pp. 203-223.

Fielding, N. G. and Fielding, J. L. (1986), Linking Data: The Articulation of Qualitative and Quantitative Methods in Social Research, Sage, Beverly Hills, CA.

Fournier, S., and Mick, D.G. (1999), "Rediscovering satisfaction”, The Journal of Marketing, 63(4), pp. 5-23.

Freeman, R. E. (1984), Strategic Management: A Stakeholder Approach, Ptiman/Ballinger (Harper Collins), Boston, MA.

Freedman, J., and Sudoyo, R. (1999), “Technology's effect on customer service: Building meaningful relationships through dialogue", Integrated Marketing Communications Research Journal, 5(1), pp. 3-8.

Giga “Seven out of Ten CRM projects Fail”, Computing, 16 August 2001, p.27.

Gourville, J.T. (2006), “Eager sellers, stony buyers", Harvard Business Review, 84(6), pp. 99106. 
Gupta, S., \& Lehmann, D. R. (2003), “Customers as assets”, Journal of Interactive Marketing, 17(1), pp. 9-24.

Gupta, S., Lehmann, D. R., \& Stuart, J. A. (2004), "Valuing customers”, Journal of Marketing Research, 41(1), pp. 7-18.

Gustafsson, A., Aksoy, L., Brady, M.K., McColl-Kennedy, J.R., Sirianni, N.J., Witell, L., and Wuenderlich, N.V. (2015), "Conducting service research that matters”, Journal of Services Marketing, 29(6/7), pp. 425-429.

Hackett, G.P. (1990), “Investment in technology-the service sector sinkhole”, Sloan Management Review, 31(2), pp. 97-103.

Hambrick, D. C. (2005), "Upper echelon theory: Origin, twists and turns, and lessons learned", In K. G. Smith \& M. A. Hitt (Eds.), Great Minds in Management: The Process of Theory Development, New York, Oxford, pp. 109-127.

Hutchinson, M., and Bouchet, A. (2014), "Organizational redirection in highly bureaucratic environments: de-escalation of commitment among Division I athletic departments", Journal of Sport Management, 28 (2), pp. 143-161.

Hutchinson, M., and Bouchet, A. (2014), “Achieving organizational de-escalation: Exit strategy implementation among United States collegiate athletic departments”, Sport Management Review, 17(3), pp. 347-361.

Janssen, O. (2003), "Innovative behavior and job involvement at the price of conflict and less satisfactory relations with co-workers", Journal of Occupational and Organizational Psychology, 76(3), pp. 347-364. 
Jayachandran, S., Sharma, S., Kaufman, P., \& Raman, P. (2005), "The role of relational information processes and technology use in customer relationship management", Journal of Marketing, 69(4), pp. 177-192.

Kerr, S. (1975), “On the folly of rewarding A, while hoping for B”, Academy of Management Journal, 18, pp. 769-783.

Kim, W. (2002), "Personalization: Definition, status, and challenges ahead", Journal of Object Technology, 1(1), pp. 29-40.

Kindström, D., Kowalkowski, C., and Sandberg, E. (2013), "Enabling service innovation: A dynamic capabilities approach”, Journal of Business Research, 66(8), pp. 1063-1073.

King, S. F., \& Burgess, T. F. (2008), "Understanding success and failure in customer relationship management", Industrial Marketing Management, 37(4), pp. 421-431.

Knowledge, (2005), “Teams cozy up to the fans with CRM's 'personalized marketing' strategy", Knowledge@,W.P Carey. Available at: http://knowledge.wpcarey.asu.edu/article.cfm?articleid=1163 (accessed 5 June 2012).

Kok, P., McKenna, T., and Brown, A. (2001), “A corporate social responsibility audit within a quality management framework", Journal of Business Ethics, 31(4), pp. 285-297.

Ko, E., Kim, S. H., Kim, M., and Woo, J. Y. (2008), “Organizational characteristics and the CRM adoption process", Journal of Business Research, 61(1), pp. 65-74.

Lee, R.P., Ginn, G.O. and Naylor, G. (2009), “The impact of network and environmental factors on service innovativeness", Journal of Services Marketing, 23(6), pp. 397-406.

Lincoln, Y. S., \& Guba, E. G. (1985), Naturalistic Inquiry (Vol. 75). Sage.

Lusch, R.F., and Nambisan, S. (2015), "Service innovation: A service-dominant logic perspective", MIS Quarterly, 39(1), pp. 155-175. 
Lusch, R.F. and Vargo, S.L. (2014), Service-Dominant Logic: Premises, Perspectives, Possibilities. Cambridge, UK, Cambridge University Press.

Markus, M. L., and Tanis, C. (2000), “The enterprise systems experience-from adoption to success", Framing the domains of IT research: Glimpsing the future through the past, 173, pp. 207-173.

Merton, R. K. (1957), Social Theory and Social Structure (rev.). New York, NY, Simon and Schuster.

Meuter, M.L., Ostrom, A.L., Roundtree, R.I., and Bitner, M.J. (2000), “Self-service technologies: understanding customer satisfaction with technology-based service encounters", Journal of Marketing, 64(3), pp. 50-64.

Mick, D.G., and Fournier, S. (1998), "Paradoxes of technology: Consumer cognizance, emotions, and coping strategies", Journal of Consumer Research, 25(2), pp. 123-143.

Miles, I. (1993), “Services in the new industrial economy”, Futures, 25(6), pp. 653-672.

Mills, C. W. (1951), White Collar, New York: Oxford University Press.

Mizik, N., and Jacobson, R. (2003), "Trading off between value creation and value appropriation: The financial implications of shifts in strategic emphasis", Journal of Marketing, 67(1), pp. 63-76.

Möller, K., Rajala, R., and Westerlund, M. (2008), "Service innovation myopia? A new recipe for client-provider value creation”, California Management Review, 50(3), pp. 31-48.

Nair, C., Chan, S., \& Fang, X. (2007), “A case study of CRM adoption in Higher Education”, In Proceedings of the 2007 Information Resources Management Association International Conference. 
Neslin, S., and Shankar, V. (2009), “Key issues in multichannel customer management: Current knowledge and future directions", Journal of Interactive Marketing, 23(1), pp. 70-81.

Neuman, W.L. (2006), Social Research Methods: Qualitative and Quantitative Approaches, $6^{\text {th }}$ ed. Boston: Pearson Education.

Nijssen, E.J., Hillebrand, B., Vermeulen, P.A., and Kemp, R.G. (2006), “Exploring product and service innovation similarities and differences", International Journal of Research in Marketing, 23(3), pp. 241-251.

Oates, G. (2013), “Exploring the links between stakeholder type, and strategic response to stakeholder and institutional demands in the public sector context", International Journal of Business and Management, 8(21), pp. 50-62.

O’Brien, D., and Slack, T (2003), “An analysis of change in an organizational field: The professionalization of English Rugby Union”, Journal of Sport Management, 17(4), pp. 417-448.

O'Cass, A., Song, M., and Yuan, L. (2013), “Anatomy of service innovation: Introduction to the special issue", Journal of Business Research, 66(8), pp. 1060-1062.

Parasuraman, A. (2000), “Technology Readiness Index (TRI) a multiple-item scale to measure readiness to embrace new technologies", Journal of Service Research, 2(4), pp. 307-320.

Parris, D. L. (2013), “Conceptually meeting expectations of Generation Y by building personalised-customised hybrid bundles to target action sports consumers", International Journal of Revenue Management, 7(2), pp. 138-154.

Parvatiyar, A., and Sheth, J. (2001), “Customer relationship management: Emerging practice, process and discipline", Journal of Economic and Social Research, 3(2), pp. 1-34.

Payne, A., and Frow, P. (2005), “A strategic framework for customer relationship management”, 
Journal of Marketing, 69(4), pp. 167-176.

Payne, A., \& Frow, P. (2006), “Customer relationship management: from strategy to implementation”, Journal of Marketing Management, 22(1-2), pp. 135-168.

Peppers, D., and Rogers, M. (1993), The One to One Future: Building Relationships One Customer at a Time, Currency Doubleday, New York, NY.

Pratt, M.G., Rockmann, K.W., and Kaufmann, J.B. (2006), “Constructing professional identity: The role of work and identity learning cycles in the customization of identity among medical residents", Academy of Management Journal, 49(2), pp. 235-262.

Prezant, J. (2013), “63\% of CRM initiatives fail”, available at: http://www.dmnews.com/crm/63 of-crm-initiatives-fail/article/303470/ (accessed 14 November 2015).

Quazi, A. M. (2003), “Identifying the determinants of corporate manager's perceived social obligations", Management Decision, 41(9), pp. 822-831.

Rigby, D. K., Reichheld, F. F., \& Schefter, P. (2002), “Avoid the four perils of CRM”, Harvard Business Review, 80(2), pp. 101-109.

Rogers, E.M. (1962), Diffusion of innovations, The Free Press, New York, NY.

Rowley, J. (2005), “Customer relationship management through the Tesco Clubcard loyalty Scheme", International Journal of Retail and Distribution Management, 33(3), pp. 194 206.

Rubin, H. J., \& Rubin, I. S. (2011), Qualitative Interviewing: The Art of Hearing Data. Sage.

Salunke, S., Weerawardena, J., and McColl-Kennedy, J.R. (2013), “Competing through service innovation: The role of bricolage and entrepreneurship in project-oriented firms", Journal of Business Research, 66(8), pp. 1085-1097. 
Schiebel, W., and Pochtrager, S. (2003), "Corporate ethics as a factor for success: The measurement instrument for the University of Agricultural Sciences”, Supply Chain Management, 8(2), pp. 116-121.

Schumpeter, J.A. (1934), “The Theory of Economic Development: An Inquiry into Profits, Capital, Credit, Interest, and the Business Cycle", Harvard University Press, Cambridge, MA.

Sheth, J. (2002), “The future of relationship marketing”, Journal of Services Marketing, 16(7), pp. 590-592.

Shaffer, G., and Zhang, Z. J. (2002), “Competitive one-to-one promotions”, Management Science, 48(9), pp. 1143-1160.

Sinkula, J. M. (1994), “Market information processing and organizational learning”, Journal of Marketing, pp. 35-45.

Slack, T., and Parent, M. M. (2006), Understanding sport organizations: The application of organization Theory, Human Kinetics.

Snyder, H., Witell, L., Gustafsson, A., Fombelle, P., and Kristensson, P. (2016), "Identifying categories of service innovation: a review and synthesis of the literature", Journal of Business Research, 99(7), pp. 2401-2408

Sok, P. and O'Cass, A. (2015), “Achieving service quality through service innovation exploration-exploitation: the critical role of employee empowerment and slack resources", Journal of Services Marketing, 29(2), pp. 137-149.

Spreitzer, G.M. (1995), "Psychological empowerment in the workplace: Dimensions, measurement, and validation", Academy of Management Journal, 38(5), pp. 1442-1465.

Srinivasan, R., \& Moorman, C. (2005), "Strategic firm commitments and rewards for customer 
relationship management in online retailing”, Journal of Marketing, 69(4), pp. 193-200.

Su, C.S. (2011), "The role of service innovation and customer experience in ethnic restaurants", The Service Industries Journal, 31(3), pp. 425-440.

Sundbo, J. (1997), "Management of innovation in services”, Service Industries Journal, 17(3), pp. 432-455.

Sundbo, J. (2000), “Organization and innovation strategy in services”, Services and the Knowledge-based economy. Continuum, London, pp. 109-128.

Timmor, Y., and Rymon, T. (2007), “To do or not to do: the dilemma of technology-based service improvement”, Journal of Services Marketing, 21(2), pp. 99-111.

Tsiotsou, R. (2013), “Sport team loyalty: Integrating relationship marketing and a hierarchy of effects", Journal of Services Marketing, 27(6), pp. 458-471.

Welty Peachey, J., and Bruening, J. (2011), “An examination of environmental forces driving change and stakeholder responses in a Football championship subdivision athletic department", Sport Management Review, 14(2), pp. 202-219.

Witell, L., Anderson, L., Brodie, R.J., Colurcio, M., Edvardsson, B., Kristensson, P., Lervik Olsen, L., Sebastiani, R., and Wallin Andreassen, T. (2015), "Exploring dualities of service innovation: implications for service research", Journal of Services Marketing, 29(6/7), pp. 436-441.

Wüenderlich, N.V., Heinonen, K., Ostrom, A.L., Patricio, L., Sousa, R., Voss, C., and Lemmink, J.G. (2015), ““Futurizing” smart service: implications for service researchers and managers", Journal of Services Marketing, 29(6/7), pp. 442-447.

Yin, R. K. (2003), Applications of Case Study Research (Applied Social Research Methods), Series, $4^{\text {th }}$, Sage Publications, Thousand Oaks, CA. 
Zauberman, G. (2003), “Intertemporal dynamics of consumer lock-in”, Journal of Research, 30(3), pp. 405-419.

Zeithaml, V.A., Berry, L.L., and Parasuraman, A. (1996), "The behavioral consequences of service quality", Journal of Marketing, pp. 31-46.

Zhou, K.Z., Yim, C.K., and Tse, D.K. (2005), "The effects of strategic orientations on technology-and market-based breakthrough innovations", Journal of Marketing, 69(2), pp. 42-60. 
Figure 1: Conceputal framework likelihood of a service technology's successful implementation

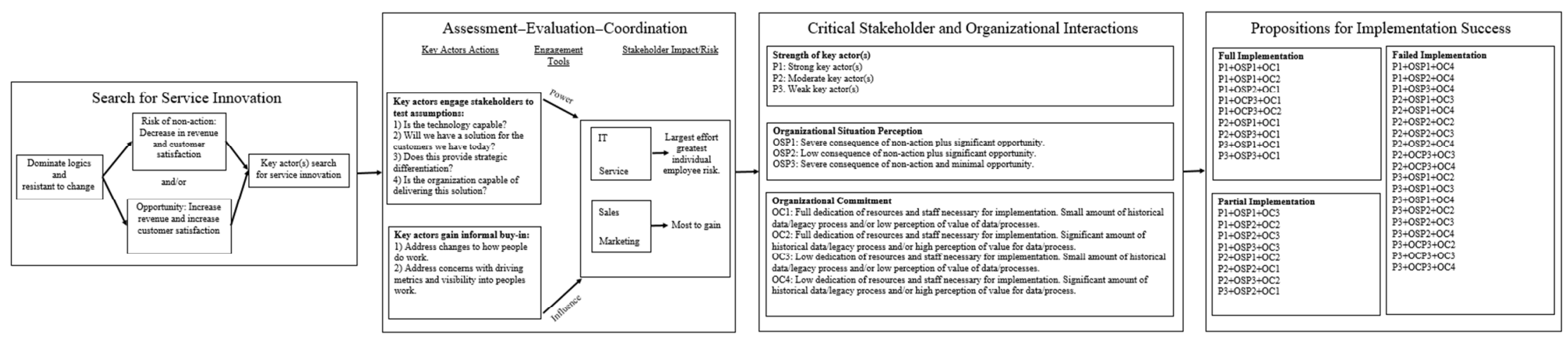

